JOURNAL OF TOURISM, HOSPITALITY AND ENVIRONMENT MANAGEMENT (JTHEM)

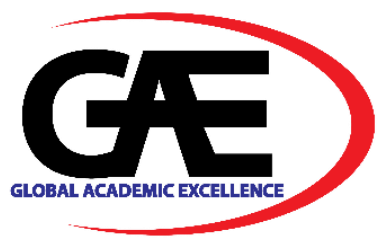

\title{
TOURISM-RELATED URBAN REGENERATION OF HISTORIC CITIES: A REGENERATION STRATEGIES FOR KOCHI, KERALA
}

\author{
Fazlur Rahman ${ }^{1 *}$, Norhazliza Halim ${ }^{2}$ \\ 1 Urban and Regional Planning, Faculty of Built Environment and Surveying, UTM, Johor Bahru-81310, Malaysia \\ Email: arfazlur121@gmail.com \\ 2 Tourism Planning Research Group, Universiti Teknologi Malaysia (UTM), Johor Bahru-81310, Malaysia \\ Email: norhaz@utm.my \\ Corresponding Author
}

\section{Article Info:}

Article history:

Received date: 01.10 .2021

Revised date: 01.11.2021

Accepted date: 15.11 .2021

Published date: 01.12.2021

\section{To cite this document:}

Rahman, F., \& Halim, N. (2021). Tourism-Related Urban Regeneration of Historic Cities: A Regeneration Strategies for Kochi, Kerala. Journal of Tourism Hospitality and Environment Management, 6 (26), 130-142.

DOI: $10.35631 /$ JTHEM.626011.

This work is licensed under $\underline{\text { C BY } 4.0}$

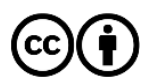

\begin{abstract}
:
The process of reinducing life into decaying assets and developing future potential with the growing tourism of a historic city is known as tourism-related urban regeneration. The assets and potential for such heritage cities consist of built heritage, traditional industries, or cultural resources. The research is based on a study of a historic city in southern India called Kochi in Kerala state, which is famous for its built heritage, cultural evolution, and traditional economic industries. It is globally known for its historical spice trade. However, at present these assets are degenerating due to their low interest in public participation in conservation and regeneration. From the 12th to 17 th century, the city Kochi (Cochin-Travancore) achieved global prosperity because of its sea-trade route, linkages with major continents, political patronage, and its existing natural resources. After independence, the city growth gets affected by inadequate development policies and low participation. With the passage of time, the city retained the built heritage and multi-shaded culture with its historical settlement patterns. The city today has shown a strong potential for tourism as there are plenty of heritage buildings, heritage settlements, and the traditional culture of the region. The city's socio-economy is dominated by traditional industries of skilled craftsmanship and service providers. But at present, this traditional economic potential and cultural heritage of the city are struggling to grow with maximum potential due to the high rate of urbanization and participation failure. Therefore, the research looks into the city's assets and its economic turbulence that could be a potential for the tourism-related urban regeneration of the region.
\end{abstract}




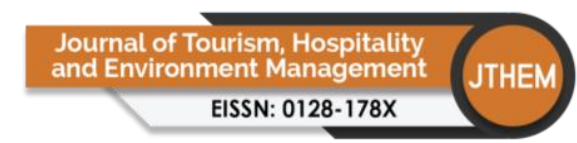

Volume 6 Issue 26 (December 2021) PP. 130-142

Keywords:

DOI 10/35631/JTHEM.626011

Tourism-Related Urban Regeneration, Traditional Industries, Public

Participation, Kochi

\section{Introduction}

Tourism means an act of spending time away from home in pursuit of pleasure, relaxation and leisure activities (Walton, 2020). It is vital for the success of many economies around the world, as it has passive benefits on host destinations through boosting the revenue of the economy, creating jobs, development of infrastructure, cultural exchange and many more (Yehia, 2019). However, for such activities, the destination needs tangible or intangible elements to promotes tourism. Kochi city has always been special for its heritage and pluralistic culture, which is directly related to its evolution (Jeychandran, 2014).

The settlement pattern of Kochi has shown an overlay of civilizations belonging to different periods with rich of historical values of Hindu, Dutch, Portuguese, and British. It has a quivering multi-shaded culture with their historical settlements (Jeychandran, 2014, 2016). The diversity in social and cultural needs of the inhabitants have been reflecting through this overlayed pattern of evolution of civilization which is developed with multi-variate urban grains (A. K. Jain, 2014). The art and architecture of these urban grains has elusive elements like traditional houses, bungalows, historic spice market, palaces and religious buildings (Bejoy \& Ramaraj, 2015; CityReport-Kochi, 2016). However, in passage of time the assets of the city getting degraded due to ignorance and low participation as high rate of urbanization recorded (Inbakaran, 2003b; Lekshmi R Nair \& Dhanuraj, 2018; Rahman \& Abd Halim, 2021), and hence it needs regeneration to promotes tourism.

Many cities in India have seen these overlaid patterns of historic art, architecture and settlement, whereas, in the process urbanization, they are struggling to survive. Therefore, it needs urban regeneration. In this process of regeneration of major urban centers has forced the local population to participate in the ease of sustainable growth of tourism (González, 2011). Hence, the process of reinducing life into decaying assets and developing future potential for growing tourism of a historic town is known as tourism-related urban regeneration (TrUR). Moreover, in case of Kochi heritage city, public has shown a decline interest of participation which affects regeneration process of the region (Nair \& Dhanuraj, 2018). Due to low participation, city lacks in physical and economic development, whereas it retains its historic art and architecture, and traditional economic skills but is struggling to sustain itself with modern trend of tourism development. This research is based on Kochi heritage city, which tries to study the problems and prospects of participation for the potential of historic assets and traditional economic activities for the tourism-related urban regeneration which has potential for the economic growth of such heritage city.

\section{Kochi: The City Profile}

Kochi, a city of Kerala state known as 'Queen of Arabian Sea' with a population of 602,046 (corporation limit) with an area of $94.88 \mathrm{~km}^{2}$ is located in the Ernakulam district which lies along the Malabar Coast of India. As per data released by Govt. of India for Census 2011, Kochi is an Urban Agglomeration coming under category of Million Plus UA/City. The total population of Kochi UA/Metropolitan region is 2,119,724 with an area of $440 \mathrm{~km}^{2}$. The male 


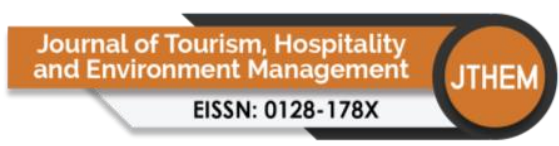

Volume 6 Issue 26 (December 2021) PP. 130-142

DOI 10/35631/JTHEM.626011

population of which is $1,044,243$ while female population is $1,075,481$. Kochi is the districtheadquarter of Ernakulam, famous for its palm green commercial city endowed with one of the finest natural harbours in the world. Kochi is the commercial capital and the most cosmopolitan city of Kerala. The hinterlands of the district lying in every direction also have been contributing to its fast trade and industrial developments.

For the administrative setup, area under Greater Cochin Development Authority (GCDA) encompasses Kochi, six municipalities and 25 panchayats covering an area of 632 sq.km and forms the largest urban agglomeration in Kerala. The city is administrated by the Corporation of Kochi (Cochin) (KOC). Kochi has 74 wards within 7 administrative zones. Due to the proximity to the Arabian Sea, Western Ghats and lagoons of Alappuzha, the city of Kochi has been a prime location for commerce and defence in South Asia since ages. The port of Kochi is the closest one in India to the international shipping routes. Due to this strategic location and the high reputation of Kerala as an international tourist destination, Kochi has grown as one of India's most visited cities.

Regarding the brief history of the city, it has important place in the world map for voyagers and traders over the centuries, as it developed as an important port for traders around the world (Josna \& Kasthurba, 2012). It has more than 2000 years back of history for development and evolution of the region. It is well known for its spices, cashew nuts, tea, coir products and handicrafts. Kochi had trade relationship with Arab, Greek and Roman, Jews, Chinese and later the Colonials (Jeychandran, 2016). Kochi has a cosmopolitan culture, highly influenced by historical trading partners, Portuguese, Dutch, Arab, Chinese, and Japanese. These trade relationships have a great influence on the cultural and religious aspects of Kerala's social structure, and also on the built heritage. Due to passage of time and with the political reforms the built heritage they left form as a vestige of past. Portuguese, the Dutch, French and then the English came here and added to the rich history of this land. Ruled by many Maharajas and Divans, this city evolved through the centuries, assimilating the cultures of the many communities from all over the globe who made it (Josna \& Kasthurba, 2012).

\section{Assets Of A Heritage City}

Every city lives and grow with their past. But few of them revive themselves and emerges as a modern city, whereas, most of the cities from the nations grown on a blue print of their origin. These blue prints are known as the history of the city, and the evolution of such cities has rich in heritage and cultural value, and behave as assets for respective cities. Kochi city has been considered as the jewel of heritage with numbers of tangible and intangible assets.it has long back history begin with $2^{\text {nd }}$ century. Moreover, from $9^{\text {th }}$ century, it has a prominent development footprint. Further, these footprints become the heritage assets for their trade and tourism. Table 01 shows the assets of Kochi heritage city.

This city is evolved with tremendous amount of heritage and cultural values, which shows a rainbow of culture within the region (D'Souza, 2013). Therefore, 'Kochi', like other cities, also have number of assets which plays key role in urban development. These assets consist of built heritage, culture, backwater, Malabar coast, and traditional economic industries (Jeychandran, 2014). However, the region noticed as high rate of urbanization, and urban density is increasing tremendously, which causes low participation in development initiatives. It results in diminishing the importance of these city's assets in economic generation in lure of tourism promotion. 
Volume 6 Issue 26 (December 2021) PP. 130-142 DOI 10/35631/ITHEM.626011

\begin{tabular}{|c|c|c|c|}
\hline \multicolumn{4}{|c|}{ Tangible heritage assets } \\
\hline & Location/region & & Location/region \\
\hline St Francis Church & \multirow{20}{*}{ Fort-Kochi } & Mattancherry Palace & \multirow{18}{*}{ Mattancherry } \\
\hline Vasco House & & Jew Town & \\
\hline David Hall & & Paradesi Synagogue & \\
\hline Old Harbor House & & Jewish Synagogue & \\
\hline Thakur House & & $\begin{array}{l}\text { Spice trade center (heritage } \\
\text { spice market) }\end{array}$ & \\
\hline Pierce Leslie Bungalow & & Old Jama masjid & \\
\hline Koder House & & Jain temple & \\
\hline Old Lighthouse Bristow & & $\begin{array}{l}\text { St George Orthodox Coonan } \\
\text { Shrine }\end{array}$ & \\
\hline Delta Study & & \multirow{2}{*}{$\begin{array}{l}\text { Pazhayannur temple } \\
\text { Jeeva Matha Church }\end{array}$} & \\
\hline Brunton Boatyard & & & \\
\hline Princess street & & Our Lady of Life Church & \\
\hline Malabar House & & Vasco Da Gama Square & \\
\hline $\begin{array}{c}\text { Santa Cruz Cathedral } \\
\text { Basilica }\end{array}$ & & Bishops House & \\
\hline Chinese fishing net & & Dutch Cemetery & \\
\hline Bolgatty Palace & & Cochin Port & \\
\hline $\begin{array}{l}\text { Thamaraparambu } \\
\text { Tempe }\end{array}$ & & Fort Emmanuel & \\
\hline Bastion Bungalow & & Hill Palace & \\
\hline Aspinwall House & & Aluva Palace & \\
\hline Tea Bungalow & & Pallipuram fort & \multirow{5}{*}{ Vypin } \\
\hline $\begin{array}{c}\text { Marth Mariam } \\
\text { Archdeacon Pilgrim } \\
\text { Church }\end{array}$ & & $\begin{array}{l}\text { St Mary's Syro Malabar } \\
\text { Cathedral Basilica }\end{array}$ & \\
\hline Malabar Coast & Western Ghat & Fort Vypin & \\
\hline Beaches & West coast & $\begin{array}{l}\text { Sree Perunpadappil } \\
\text { Bhagavathi temple }\end{array}$ & \\
\hline Willington Island fort & $\begin{array}{l}\text { Willington } \\
\text { Island }\end{array}$ & Elamkunnapuzha Temple & \\
\hline \multicolumn{4}{|c|}{ Intangible Heritage assets } \\
\hline Cultural Fest & Pongal & Mohiniyattam & Kathakali \\
\hline Mudiyettu & Kalaripayattu & Padayani & Koodiyattam \\
\hline
\end{tabular}

Table 1: Kochi City Heritage Assets

Source: Authors' synthesis

\section{Land Use Of The Kochi City Region}

Kerala is considered as one of the fastest urbanizing states in India and half of the population residing in urban areas. Kochi is situated on the western ghat of Malabar coast of India in Ernakulam district of Kerala. Kochi heritage city is a part of greater Cochin and consists of Corporation of Kochi with five municipality and eleven panchayats. Total area constituted is about $369.72 \mathrm{~km}^{2}$.

In early 90s, the urban fabric of Kochi city was moderate, moreover, it has a prominent sign of rapid urbanization of the region. In last two decades the Kochi city shown a rapid urbanization. 
Volume 6 Issue 26 (December 2021) PP. 130-142 DOI 10/35631/JTHEM.626011

Therefore, spatial growth and land use of Kochi city has shown a keypoint transformation in land use with about $43.43 \%$ predominately in residential use followed by industrial, commercial, industrial, transportation, agricultural and many more (see table-02), which makes the city more potential for development of tourism industry by integrating tourism with urban regeneration programme, as per the city development plan for Kochi city,2031 (Kumara, 2019).

Figure 1: Existing landuse of Kochi, 2009

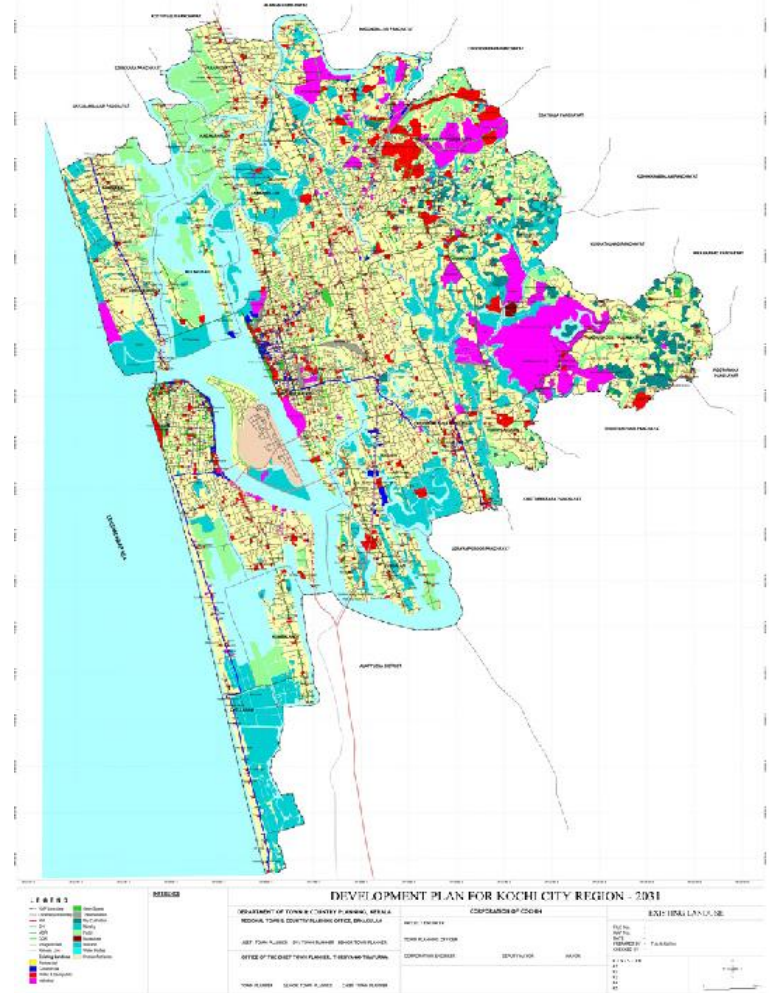

Figure 1: Existing Landuse of Kochi, 2009

Source: Master Plan of Kochi city-2009 


\begin{tabular}{|c|c|c|c|c|c|c|c|c|c|}
\hline \multirow{2}{*}{ Year } & \multicolumn{3}{|c|}{ India } & \multicolumn{3}{c|}{ Kerala } & \multicolumn{3}{c|}{ Ernakulam } \\
\cline { 2 - 11 } & Total & Urban & \%urban & Total & Urban & \%urban & Total & Urban & \%urban \\
\hline 1971 & 5481.60 & 1091.14 & 19.91 & 213.47 & 34.66 & 16.24 & 23.83 & 6.36 & 26.69 \\
\hline 1981 & 6833.30 & 1594.63 & 23.34 & 254.54 & 47.71 & 18.74 & 25.35 & 10.03 & 39.56 \\
\hline 1991 & 8463.03 & 2176.11 & 25.71 & 290.99 & 76.80 & 26.39 & 28.17 & 13.73 & 48.74 \\
\hline 2001 & 10270.20 & 2853.55 & 27.78 & 318.39 & 82.67 & 25.97 & 31.06 & 14.77 & 47.56 \\
\hline 2011 & 12101.90 & 3770.96 & 31.13 & 333.87 & 159.32 & 47.72 & 32.82 & 22.35 & 68.10 \\
\hline
\end{tabular}

Table 2: Land Use Classification For Kochi Heritage City-2009

Source: Master Plan of Kochi city-2009

\section{Urban Growth Rate And Density For Kochi City Region}

Urbanization in Indian cities are considered as one of the most challenging sectors for policy makers and developers. Urbanization trend in Kerala is at an alarming rate. Kerala is one of the fastest growing urbanizing states in India and as per government record, half of the population residing in urban areas (Kumara, 2019). In 2001 census, the urban population of Kerala was noticed as $25.97 \%$ which has increased to $47.72 \%$ in 2011 census. Similarly, for the Kochi city in Ernakulam district the urban population was $47.56 \%$ in 2001 which has increased to $68.10 \%$ in 2011, and therefore, the district stands the highest rate of urbanization in the state of Kerala, the details are shown in table 03 .

\section{Table 3: Urbanization Trends In India, Kerala State And Ernakulam District}

\begin{tabular}{|c|c|c|}
\hline Land use-2009 & Area (Ha) & \% to gross area \\
\hline Residential & 16057.9 & 43.43 \\
\hline Commercial & 367.1 & 0.99 \\
\hline Public and Semipublic & 1538.37 & 4.16 \\
\hline Industrial & 2123.18 & 5.74 \\
\hline Transportation & 1486.35 & 4.02 \\
\hline Park and Open spaces & 113.79 & 0.31 \\
\hline Hazardous & 23.66 & 0.06 \\
\hline Paddy land & 6817.55 & 18.44 \\
\hline Dry agriculture land & 754.06 & 2.04 \\
\hline Water bodies & 7011.43 & 18.96 \\
\hline Port land & 281.12 & 0.76 \\
\hline Other (SEZ and unclassified area) & 397.3 & 1.07 \\
\hline Total & 36971.81 & 100.00 \\
\hline
\end{tabular}

Source: Authors' synthesis from Census of India 1971-2011

Table 3 explains the growth pattern of the Kochi region. It shows the growth pattern of Ernakulam district with growth rate of state since 1971 to current census, it has shown the overall density of the Kochi city of 33.06 person per hectare. It is noticed that Kochi corporation is having maximum population density of 64.33 persons per hectare, i.e., 1072 persons per sq $\mathrm{km}$. 


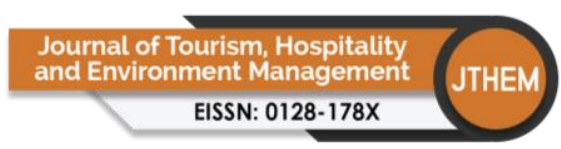

Volume 6 Issue 26 (December 2021) PP. 130-142

DOI 10/35631/JTHEM.626011

\section{Significance Of Tourism}

Tourism has emerged as an important sector globally, contributing to around 10 per cent of global GDP, 9.4 per cent of global employment, 7 per cent of global exports and 30 per cent of service exports (World Tourism Organization, 2016). International tourism receipts earned by destinations worldwide surged from USD 2 billion in 1950 to USD 1260 billion in 2015. International tourist arrivals worldwide also increased from 25.3 million in 1950 to 1186 million in 2015, it reaches to 1.4 billion in 2018, and it is projected to 1.8 billion in 2030 (UNWTO-globaldit \& idt, 2018). Moreover, Tourism growth is no longer concentrated in the industrial countries, as emerging markets have also developed into major players in the global tourism industry since the 1980s. Global studies have shown that the tourism sector has performed better in relatively free market conditions, where the role of the governments would be facilitators and supporters with the private sector playing a major role in tourism development (Zainal, Radzi, Hashim, Chik, \& Abu, 2012).

India is very rich with its various climatic conditions, cultural edifices and historical assets. It attracts people of all profiles, ages and interests and caters to their needs. India's tourism history dates back to the ancient times and it was foreigners enchanted by India's wild, vibrant and serene beauty (Harini \& Indira, 2014; Kurian, 2018). According to the Travel and Tourism Competitiveness Report 2015, India has moved up 13 steps to the $52^{\text {nd }}$ position on a list of 140 countries and 11 among the Asia Pacific countries in terms of their travel and tourism competitiveness (Brata \& Pemayun, 2018; Crotti \& Misrahi, 2015). International tourist arrival in India reached a record of 10.89 million in 2019, $3.1 \%$ more from 2018, according to the UN World Tourism Organization (UNWTO, 2019).

Being the commercial and industrial capital of western ghat state in Malabar coast of India, Kochi is home for a variety of modern and traditional activities (Kumara, 2019). In a travel and tourism report (CII \& KPMG, 2013) mentioned Kerala as the first Indian state which has declared tourism as an industry and also first to launch the Tourism Visio-2025 strategic document. Kerala-God's Own Country, registered as brand with registered trademarks of Government of India (the hindubusinessline, 2003).

Kerala Tourism consists of 10 per cent of states GDP, and 23.5 per cent of total employment in the state's contribution has been reported by official statistics (EconomicReview, 2018). As it has huge potential for contribution to economic growth and employment, it has been suggested in global tourism studies that the benefits from tourism in many places are overestimated (Steyn \& Spencer, 2012). This is because of the issues in tourism as fail to define the tourists and failure in measurement of the economic impact of tourism in Kerala. Thus, huge investment has been made by state in tourism depends on the enhancement the status of tourist definition at the destinations. 
Volume 6 Issue 26 (December 2021) PP. 130-142 DOI 10/35631/JTHEM.626011

Table 4: Tourism statistics of Kerala 2009-2019, Ernakulam district tourists

\begin{tabular}{|c|c|c|c|c|c|c|c|c|c|c|c|c|}
\hline & \multicolumn{6}{|c|}{ Kerala } & \multicolumn{6}{|c|}{ Ernakulam District (Kochi) } \\
\hline Year & $\begin{array}{l}\text { Total no } \\
\text { of } \\
\text { Tourists }\end{array}$ & $\begin{array}{c}\% \\
\text { increase }\end{array}$ & $\begin{array}{l}\text { Foreign } \\
\text { Tourist }\end{array}$ & $\begin{array}{c}\% \\
\text { increase }\end{array}$ & $\begin{array}{l}\text { Domestic } \\
\text { Tourists }\end{array}$ & $\begin{array}{c}\% \\
\text { increase }\end{array}$ & $\begin{array}{l}\text { Total no } \\
\text { of } \\
\text { Tourists }\end{array}$ & $\begin{array}{c}\% \\
\text { increase }\end{array}$ & $\begin{array}{c}\text { Foreign } \\
\text { Tourist }\end{array}$ & $\begin{array}{c}\% \\
\text { increase }\end{array}$ & $\begin{array}{c}\text { Domestic } \\
\text { Tourists }\end{array}$ & $\begin{array}{c}\% \\
\text { increase }\end{array}$ \\
\hline 2009 & 8470795 & & 557258 & & 7913537 & & 2058112 & & 239364 & & 1818748 & \\
\hline 2010 & 9254340 & 9.25 & 659265 & 18.31 & 8595075 & 8.61 & 2265418 & 10.07 & 277675 & 16.01 & 1987743 & 9.29 \\
\hline 2011 & 10114440 & 9.29 & 732985 & 11.18 & 9381455 & 9.15 & 2478100 & 9.39 & 308674 & 11.16 & 2169426 & 9.14 \\
\hline 2012 & 10870550 & 7.48 & 793696 & 8.28 & 10076854 & 7.41 & 2682021 & 8.23 & 330390 & 7.04 & 2351631 & 8.40 \\
\hline 2013 & 11715954 & 7.78 & 858143 & 8.12 & 10857811 & 7.75 & 2897887 & 8.05 & 352314 & 6.64 & 2545573 & 8.25 \\
\hline 2014 & 12618777 & 7.71 & 923366 & 7.60 & 11695411 & 7.71 & 3097715 & 6.90 & 372997 & 5.87 & 2724718 & 7.04 \\
\hline 2015 & 13443050 & 6.53 & 977479 & 5.86 & 12465571 & 6.59 & 3281537 & 5.93 & 383643 & 2.85 & 2897894 & 6.36 \\
\hline 2016 & 14210954 & 5.71 & 1038419 & 6.23 & 13172535 & 5.67 & 3480812 & 6.07 & 407653 & 6.26 & 3073159 & 6.05 \\
\hline 2017 & 15765390 & 10.94 & 1091870 & 5.15 & 14673520 & 11.39 & 3739061 & 7.42 & 453973 & 11.36 & 3285088 & 6.90 \\
\hline 2018 & 16701068 & 5.94 & 1096407 & 0.42 & 15604661 & 6.35 & 3935064 & 5.24 & 488175 & 7.53 & 3446889 & 4.93 \\
\hline 2019 & 19574004 & 17.20 & 1189771 & 8.52 & 18384233 & 17.81 & 4582366 & 16.45 & 522232 & 6.98 & 4060134 & 17.79 \\
\hline
\end{tabular}

Source: Authors' synthesis from Kerala Tourism statistics 2009-2019, Government of Kerala, India

In an interest of Kerala tourism, it is important to established the relationship between tourists and service providers among the state. Table 04 below give an account of tourism growth and trend in Kerala and Ernakulam District (Kochi city). They include the details of tourists' arrival and the earnings from the tourism industry.

The earning from tourism in Kerala and Ernakulam district (Kochi city) shown in table 04. It is noticed that on an average about $25 \%$ of the tourist arriving in Kerala is visiting to the Ernakulam district, which shows, there is a potential for development of urban region of Kochi city by integrating tourism in urban regeneration process.

Table 5: Earnings From Tourism 2010-2019 (₹ In Crore), Kerala State And Ernakulam District

\section{Kerala}

\begin{tabular}{|c|c|c|c|c|c|}
\hline Year & $\begin{array}{c}\text { Foreign Exchange } \\
\text { Earnings (₹ in } \\
\text { Crore) }\end{array}$ & $\begin{array}{c}\% \\
\text { increase }\end{array}$ & $\begin{array}{c}\text { Earnings from } \\
\text { Domestic } \\
\text { tourists (₹ in } \\
\text { Crore) }\end{array}$ & $\begin{array}{c}\text { Total revenue } \\
\text { generated from } \\
\text { Tourism (direct \& } \\
\text { indirect) (₹ in } \\
\text { Crore) }\end{array}$ & $\begin{array}{c}\% \\
\text { increases }\end{array}$ \\
\hline 2010 & 3797.37 & 33.09 & & 17348 & 31.12 \\
\hline 2011 & 4221.99 & 11.18 & 10131.97 & 19037 & 9.735993 \\
\hline 2012 & 4571.69 & 8.28 & 10883 & 20430 & 7.317329 \\
\hline 2013 & 5560.77 & 21.63 & 11726.44 & 22926.55 & 12.22002 \\
\hline 2014 & 6398.93 & 15.07 & 12981.91 & 24885.44 & 8.544199 \\
\hline 2015 & 6949.88 & 8.61 & 13836.78 & 26689.63 & 7.249982 \\
\hline 2016 & 7749.51 & 11.51 & 15348.64 & 29658.56 & 11.12391 \\
\hline 2017 & 8392.11 & 8.29 & 17608.22 & 33383.68 & 12.56002 \\
\hline 2018 & 8764.46 & 4.44 & 19474.62 & 36258.01 & 8.609985 \\
\hline 2019 & 10271.06 & 17.19 & 24785.62 & 45010.69 & 24.13999 \\
\hline & & Ernakulam district (Kochi) & & \\
\hline
\end{tabular}




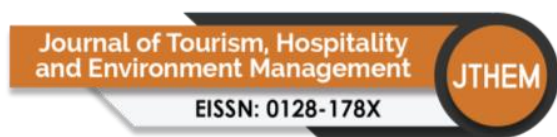

Volume 6 Issue 26 (December 2021) PP. 130-142

DOI 10/35631/JTHEM.626011

\begin{tabular}{|c|c|c|c|c|}
\hline Year & $\begin{array}{c}\text { Foreign Exchange } \\
\text { Earnings (₹ in } \\
\text { Crore) }\end{array}$ & $\begin{array}{c}\% \\
\text { increase }\end{array}$ & $\begin{array}{c}\text { Total revenue generated from } \\
\text { Tourism (direct \& indirect) (₹ in } \\
\text { Crore) }\end{array}$ & $\begin{array}{c}\% \\
\text { increases }\end{array}$ \\
\hline 2017 & 3489.24 & 13.36 & 9541.64 & 14.84 \\
\hline 2018 & 3902.37 & 11.84 & 10533.78 & 10.40 \\
\hline 2019 & 4508.32 & 15.53 & 12816.5 & 21.67 \\
\hline
\end{tabular}

Source: Authors' synthesis from Kerala Tourism statistics 2009-2019, Government of Kerala, India

\section{Tourism-Related Urban Regeneration In Kochi Heritage City}

Tourism-related urban regeneration crosses over many different policy and participatory domains and involves a wide range of organisations with various interests (Kim, 2012). The relationships between the organisations were not always based on resource exchanges. Therefore, it shows a need of study of actors' interaction in the case study areas, where tourismrelated urban regeneration happens. The interaction has expressed through the participatory network mapping. The mapping exercise is helpful in order to summarise the pattern of interorganisational interaction, such as interactions between the public sector and the private sector organisations and also to the partnership working between different organisations.

Progressively, tourism is widely seen as a tool for urban regeneration and many old cities especially in developing countries such as India, incorporate tourism into their regeneration process (Inbakaran, 2003a). In the case of Kochi, Kerala, public participation plays a key factor to support the urban regeneration process based on tourism development (Menon \& Edward, 2014). Tourism- related urban regeneration (TrUR) is an interesting field of research in which to investigate such a governance trend due to the complicated and fragmented nature of its planning and development processes are taking place (Kim, 2012).

In addition, from the perspective of tourism studies, the regeneration potential in tourism is based on the revival of old cities (Lee, 2007a; Potter, 2012). The urban regeneration's potential comes from tourism having the ability to create jobs for local communities, which increases the economic regeneration from tourism activities into the local economy with the potential of additional economic multiplier effect, and the creation of a new status and image for the host (Swarbrooke, 2000). In the urban core, tourism has become a key component of urban policies tied in to place-marketing and urban re-imaging strategies (Page \& Hall, 2003). City authorities have had to market their cities in order to seek new inward investment, and create new attractive spaces within the city as part of the development process, and this gives rise to the need to manage visitors in cities (Tylor, 2000). As tourism development has become particularly important in the urban regeneration strategies of traditionally industrial cities in recent years, tourism seems to be a potential cure to most of their urban regeneration problems.

To kick off the study of urban regeneration of a historic city, Kochi heritage city has great potential because it has a unique historical trajectories and spatial layouts and also possess a contemporary existence. The Kochi city has palimpsest urbanscapes that concurrently exhibit remnants of colonial culture, modernity, national predicaments, and transnational sociocultural connections. Furthermore, the monuments and heritages of such places are the vehicles that link their surrounding towns to global networks especially through tourism.

Government of Kerala has proposed numbers of development initiatives including urban revival and regeneration of heritage centres around the state. They propose theses development 


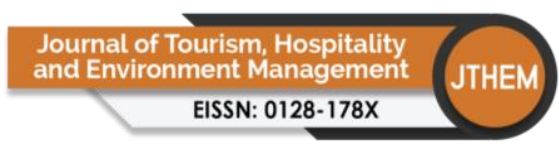

Volume 6 Issue 26 (December 2021) PP. 130-142

DOI 10/35631/JTHEM.626011

plans in their five-year plan (CityReport-Kochi, 2016). INTACH was a member of the subgroup of the Working Group on Tourism for the 12th five-year plan. Constituted by the Planning Commission, the Division prepared and submitted heritage tourism scheme for the restoration/refurbishment of heritage buildings for adaptive re-use for tourism proposes. The objective of this Scheme is to restore and refurbish the built heritage of this country (unprotected by the A.S.I. and the State Archaeological Surveys) and tailor it for adaptive reuse for tourism purposes depending on the typology, size space, location and the quality of the heritage property. They can be utilized for purposes such as setting-up museum, performing art, theatres, conference and seminar spaces, heritage hotels, walk in heritage experiences, heritage cuisine, restaurants and many other.

\section{Problems In TrUR And Need For Regeneration}

Over the last two decades, some Indian cities including Kochi heritage city, based on traditional industries have experienced a variety of urban problems, such as decline of the tourism sector leading to increasing unemployment, results livelihood depression (P. Jain, 2009). And in the process of urban development, cities continue to push beyond their erstwhile limits, the old city areas neglected and results the over loss of importance of the old city (Sonal, 2014). As a result, the need of urban regeneration to improve the economic, physical environment and social problems have become a significant issue in such cities. In order to transform the process of decline, these traditional cities have become more aware of the need to re-image themselves on an attractive place to visit, invest and live (Savini, 2011). Today, this process of re-imaging from the perspective of city authorities remains a priority concern in order to face the increasing popularity among visitors and investors for the new development opportunities (Lee, 2007b; Shyam et al., 2019), and this is called need for tourism-related urban regeneration.

During 1970s and early 1980s, many heritage and industrial cities experienced the decline and loss of their traditional economic industries, for example, spice market in Kochi, Kerala, saw the decline of spice route economy, fishing industry of Kochi heritage city has losses their economic identity in the state of Kerala (Josna \& Kasthurba, 2012). Thereafter, in early 20s due to urban agglomeration, cultural heritage of the region is in great stress (Bejoy \& Ramaraj, 2015). The socio-economic decline was accompanied by many associated social, physical and environmental problems. Therefore, these cities were in a need of urban regeneration with local participation in order to retain the sociability of the region.

\section{Conclusion}

On reviewing the literatures of many scholars related to tourism-related urban regeneration in Kochi heritage city concluded that, it is an empirical field of policy which trying to address the perceived problems of urban decline in all their complexity when urban regeneration happens to any region, tourism plays a very crucial role in their development process.

Further it is concluded that, increasing numbers of Asian cultural-heritage cities including Kochi heritage city have encountered significant economic decline since 1980s. Tourism has been widely accepted by these heritage cities as playing a key role in reconfiguring urban areas during a period of rapid economic change (Buhalis, Maitland, \& Viveiros, 2000; Karski, 1990). Thereafter, for the tourism-related urban regeneration of Kochi heritage city it is concluded that, public participation in tourism act as an agent for economic regeneration and links with cultural heritage that many urban places are experiencing. It is further concluded with the following 


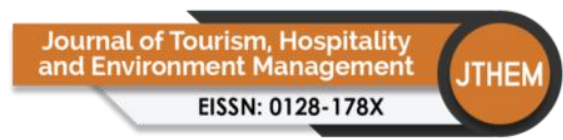

Volume 6 Issue 26 (December 2021) PP. 130-142

DOI 10/35631/JTHEM.626011

- Due high rate of urbanization of Kochi city region, low participation in such regeneration process has been identified.

- The historic ambience of Kochi region is in stress. Most of the efforts have not given sufficient base to uplift the assets of the town.

- The urban development authority and other organizations need public participation and a better administrative setup, as the decaying heritage and traditional economic activities have raised the issue of sustainability of the town.

- The heritage sites and natural scenic places are gradually degrading and some of them need immediate protection.

- The dominant part of economy is shared by traditional industries, which is struggling to sustain itself because of reduced public participation and incompetent governance system.

Further, the Kochi city region has many environmental and traditional assets that could be recycled for present needs. Recycling these assets could uplift local poverty with existing skills for the sustainability of the region.

\section{Recommendations}

For the effective public participation in such tourism-related urban regeneration, it is recommended that the incorporation of tourism as a policy response can secure urban regeneration by bringing tourists and employment opportunities for improving the city image. This type of incorporation of tourism in physical urban regeneration is most evident in sitebased regeneration projects which expect visitors activities to support new facilities such as cultural, sport and leisure attractions (Aiesha \& Evans, 2007). It is further recommended the following

- For socio-political economic management of the city, it is usually needed an entrepreneurial ideology which helps to attract capital for regeneration process.

- To reduction of stress from high rate of urbanization, it is necessary to get participation in effective management system.

- To reduce the stress on historic ambience of the Kochi city, it is important to conserve the city's assets and promote with tourism.

- To uplift from the economic stress of the region, it is important to regenerate the traditional economic industries of the region by incorporating them into tourism promotion.

Further, it is recommended that, for effective public participation the decentralisation of city centres would serve as conventional approach in accomplishing the targets of the programme.

\section{References}

Aiesha, R., \& Evans, G. (2007). VivaCity: mixed-use and urban tourism. In M. K. Smith (Ed.), Tourism, culture and regeneration (pp. 35-48). Wallingford: CAB International.

Bejoy, J., \& Ramaraj, K. (2015). Impacts of Sustainable Cultural Tourism in Fort Kochi, Kerala. Shanlax International Journal of Arts, Science \& Humanities, 3(1), 109-115.

Brata, I. B., \& Pemayun, A. G. P. (2018). Human Resource Competency Tourism Bali together with ASEAN Economic Community. International research journal of management, IT and social sciences, 5(2), 186-194.

Buhalis, D., Maitland, R., \& Viveiros, L. (2000). Urban tourism. Annals of Tourism Research, Elsevier, 1(27), 229-231. 


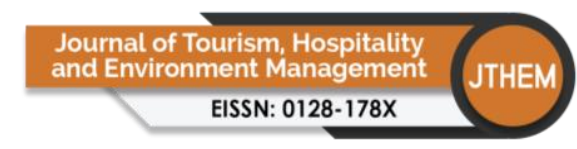

Volume 6 Issue 26 (December 2021) PP. 130-142

DOI 10/35631/JTHEM.626011

CII, \& KPMG. (2013). Travel and Tourism in India: A Developmental Perspective. Retrieved from

CityReport-Kochi. (2016). Kerala Sustainable Urban Development Project-Kochi city. In (Vol. 2). Ernakulam, Kerala: Local Self Government Department, Government of kerala.

Crotti, R., \& Misrahi, T. (2015). The Travel \& Tourism Competitiveness Report 2015-Growth through Shocks. Paper presented at the World Economic Forum.

D'Souza, R. E. (2013). The Indian Biennale EffectThe Kochi-Muziris Biennale 2012. Cultural Politics, 9(3), 296-312.

EconomicReview. (2018). Gov. of Kerala. Thiruvananthapuram, Kerala, India: Kerala State Planning Board, Thiruvananthapuram from http://spb.kerala.gov.in/images/pdf/whats_new/Vol1_E.pdf.

González, S. (2011). Bilbao and Barcelona 'in motion'. How urban regeneration 'models' travel and mutate in the global flows of policy tourism. Urban studies, 48(7), 13971418.

Harini, K., \& Indira, M. (2014). Growth and prospects for service sector in globalized economy: A study of Indian tourism industry. International Journal of advanced research in Management and Social Sciences, 3(3), 63-74.

Inbakaran, R. J. (2003a). Tourism and the Indian Urban Regeneration: The Importance of Urban Tourism in India-A General Perspective. In New Approaches in Tourism Management (pp. 17). New Delhi, India: Publisher: Abhijeet Publications.

Inbakaran, R. J. (2003b). Tourism and the Indian Urban Regeneration: The Importance of Urban Tourism in India: A General Perspective. In M. R. Nigam (Ed.), New Approaches in Tourism Management (pp. 23). New Delhi: Abhijeet Publications.

Jain, A. K. (2014). The Kochi Muziris Biennale: its Impact on The Socio--Cultural Aspects of India. University College London, London.

Jain, P. (2009). Revitalization of Walled City, Jaipur. (Master of Urban and Rural Planning), Indian Institute of Technology Roorkee, Roorkee.

Jeychandran, N. (2014). Memory, Heritage, and Cultural Display in the Former Colonial Port Cities of Elmina (Ghana) and Fort Kochi (India). (PhD Dissertation), UCLA,

Jeychandran, N. (2016). Colonial Spaces, Postcolonial Narratives: The Exhibitionary Landscape of Fort Cochin in India. In Chambers I, Angelis A, Ianniciello C, Orabona M, \& Q. M (Eds.), The Postcolonial Museum (pp. 51-61). New York, USA: Routledge.

Josna, R. P., \& Kasthurba, A. K. (2012). Symbiosis of Conservation and Development: Historic City of Kochi, Kerala, India. Paper presented at the International Conference on Transport, Civil, Architecture and Environment engineering (ICTCAEE'2012) Dubai (UAE).

Karski, A. (1990). Urban tourism: A key to urban regeneration. The Planner, 76(13), 15-17.

Kim, S. Y. (2012). Tourism-related urban regeneration in two UK city regions. Sheffield Hallam University, Available from Sheffield Hallam University Research Archive

Kumara, H. (2019). Integrating Plan for Backwaters Transportation with Tourism Development: A Case Study of Kochi City Region. International Journal of Urban Management and Energy Sustainability, 2(1), 1-8.

Kurian, R. (2018). Impact of backwater Tourism in Vembanad region in Kerala with special reference to Kumarakom Gramapanchayat.

Lee, C. b. (2007a). An investigation into the interrelationship between tourism and cultural policy in the discource of urban regeneration. Retrieved from Birmingham: 


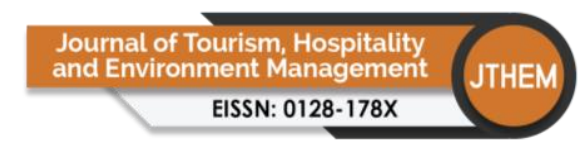

Volume 6 Issue 26 (December 2021) PP. 130-142 DOI 10/35631/JTHEM.626011

Lee, C. b. (2007b). An investigation into the interrelationship between tourism and cultural policy in the discource of urban regeneration. In. Birmingham: University of Birmingham Research Archives.

Lekshmi R Nair, \& Dhanuraj, D. (2018). Kerala Tourism - The Role of the Government and Economic Impact. Retrieved from Trivendram, Kerala:

Menon, S., \& Edward, M. (2014). Public private partnerships in tourism-a case study of Kerala Travel Mart. African Journal of Hospitality, Tourism and Leisure, 4(2), 7.

Nair, L. R., \& Dhanuraj, D. (2018). Kerala Tourism - The Role of the Government and Economic Impacts, Centre for Public Policy Research. Retrieved from Kerala, India:

Page, S., \& Hall, C. M. (2003). Managing Urban Tourism. Harlow: Pearson Education.

Potter, R. (2012). Urbanisation and planning in the third world: Spatial perceptions and public participation: Routledge.

Rahman, F., \& Abd Halim, N. (2021). Participatory Economy and Overtourism: The LongTerm Effect on the Economic Dynamics of Fort-Kochi. Studies of Applied Economics, 39(4). doi:https://doi.org/10.25115/eea.v39i4.4170

Savini, F. (2011). The Endowment of Community Participation: Institutional settings in two Urban Regeneration projects. International Journal of Urban and Regional Research, 35(5), 49-68. doi:10.1111/j.1468-2427.2010.00997

Shyam, S. S., Joseph, L., Elizabeth James, H., Shinu, A., Athira, N., \& Rosey Xavier, S. (2019). Assessing the Alternative Livelihood Options for Climate Change Vulnerable Coastal Fishing Villages in Kerala, India. International Journal of Environment and Climate Change (Previously known as British Journal of Environment \& Climate Change), 9(4), 204-216.

Sonal, S. (2014). Reclaiming Urban Identity: Framework for Urban Regeneration of Patna City Area. Journal of Civil Engineering and Environmental Technology, 1(2), 93-97.

Steyn, J., \& Spencer, J. (2012). Climate change and tourism: implications for South Africa: tourism and adventure. African Journal for Physical Health Education, Recreation and Dance, 18(1), 1-19.

Swarbrooke, J. (2000). Tourism, economic development and urban regeneration: a critical evaluation. In Development in Urban and Rural Tourism: Reflections on International Tourism (pp. 269-285). Sunderland: the Centre for Travel and Tourism/ Business Education Publishers.

Tylor, D. (2000). A framework for analysis urban tourism. In Development in Urban and Rural Tourism: Reflections on International Tourism (pp. 287-299). Sunderland: the Centre for Travel and Tourism/ Business Education Publishers.

UNWTO-globaldit, \& idt. (2018). Global Report on Inclusive Tourism Destinations Model and success stories. Retrieved from Middle east: https://www.unwto.org/middleeast/publication/global-report-inclusive-tourism-destinations-model-and-successstories

UNWTO. (2019). UNWTO Annual Report. Retrieved from Madrid, Spain:

Walton, J. K. (2020). Tourism. Encyclopedia Britannica. . In Leisure and Nightlife.

Yehia, Y. (2019). The Importance of Tourism on Economies and Businesses. globalEDGE blog, (1). Retrieved from globalEDGE newsletter website:

Zainal, A., Radzi, S., Hashim, R., Chik, C., \& Abu, R. (2012). Current issues in hospitality and tourism: Research and innovations (1 ed. Vol. 1): CSR Press, Taylor \& Francis Group. 